\title{
Incidence of Listeria monocytogenes in Meat Product Samples by Real- Time PCR
}

\author{
Miroslava Kačániová1 ${ }^{\star}$, Maciej Kluz², Jana Petrová ${ }^{1}$, Martin Mellen ${ }^{3}$, Simona Kunová ${ }^{1}$, Peter Haščík ${ }^{1}$ and L'ubomír Lopašovský1 \\ ${ }^{1}$ Faculty of Biotechnology and Food Sciences, Slovak University of Agriculture in Nitra, Nitra, Slovak Republic \\ ${ }^{2}$ Department of Biotechnology and Microbiology, University of Rzeszow, Rzeszow, Poland \\ ${ }^{3}$ Hydina Slovakia, s.r.o., Nová L'ubovňa 505, Nová L'ubovňa 065 11, Slovakia
}

\begin{abstract}
The aim of this study was to trace a contamination of meat products with Listeria monocytogenes. Step One real time Polymerase Chain Reaction (PCR) was used. We used the PrepSEQ Rapid Spin Sample Preparation Kit for isolation of DNA and MicroSEQ ${ }^{\circledR}$ Listeria monocytogenes Detection Kit for the real-time PCR performance. We found out the strains of Listeria monocytogenes in hundred samples of meat products with no incubation. There was Internal Positive Control (IPC) in 40 samples. Our results showed that the real time PCR assay tested in this study might detect Listeria monocytogenes in meat product samples with no incubation sensitively.
\end{abstract}

Keywords: Meat product samples; Real time PCR, Listeria monocytogenes

\section{Introduction}

It is known that the incidence of food-borne illnesses in both industrialized as well as in non-industrialized countries [1,2] has increased. This could be the result of some major changes in food production, preservation, storage and consumption as well as in globalization and liberation of food trade and importation of foods.

Listeria monocytogenes is a human pathogen which is widely distributed in the environment $[3,4]$. Meat products are one of the major sources of L. monocytogenes [5-7]. The International Commission on Microbiological Specification for Foods concluded that $100 \mathrm{CFU}$ of L. monocytogenes per gram of food at the time of consumption is acceptable for consumers. This statement is in regard to the fact that the clinical cases of listeriosis are usually associated with high loads of L. monocytogenes, as it is difficult to eradicate listeriae from the environment of the food processing plants [8].

Several studies of real-time PCR-based detection of L. monocytogenes in food have been published $[9,10]$ and several validated real-time PCR based kits are commercially available (iQ-Check Listeria, Bio-Rad, TaqMan Listeria, Applied Biosystems, BAX system PCR Assay Listeria monocytogenes, DuPont Qualicon). The real-time PCR detection is preceded by a single-step or a two-step enrichment using media of different selectivity in these complete methods. These methods are used by different enrichment and DNA preparation approaches to reach the increasing numbers of live cells to a detectable level and dilution of dead L. monocytogenes cells as well as food-borne PCR inhibitors [11].

The conventional testing methods for the detection of $L$. monocytogenes in food involves growth in pre enrichment medium, followed by growth on selective medium and a battery of confirmatory biochemical and serological tests [12]. These methods are laborintensive and time-consuming and they often take up to 10 days. The rapid alternative method is real-time ( $\mathrm{RTi}$ )-PCR which allows an accurate and unambiguous identification and a precise quantification of nucleic acid sequences $[4,13]$. Furthermore the lack of post-PCR steps reduces the risk of cross-contamination and allows high throughput and automation.

O'Grady et al. [14,15] described a qPCR assay for the specific detection of L. monocytogenes in food samples. Positive deviation was observed in ten analyzed samples. There was a possible explanation for these discordant results are that DNA from dead or viable but non culturable L. monocytogenes cells detected by the alternative method in the food matrix. Alternatively, these positive deviations might results which indicated this new method is more sensitive than the Listeria precis method for detecting L. monocytogenes in RTE pork products. Furthermore, negative deviation was not detected which demonstrates the robustness of the alternative method as food components such as organic compounds, calcium ions, glycogen and lipids have been demonstrated to inhibit PCR [16].

Therefore, the aim of this study was to determine the level of contamination in different meat products samples that are ready for human consumption in Slovakia by isolating and identifying of Listeria monocytogenes by Step One real time PCR.

\section{Material and Methods}

\section{Sample design}

Altogether 100 samples collected in Slovakia from 2009 to 2013. Samples included ready-to-eat meat product samples (100 g each) were collected from supermarkets in the Slovakian localities-mentioned above. Among the samples were Soft Meat Products (SMP): Ratatouille sausage $(n=12)$, ham sausage $(n=8)$, ipelská sausage $(n=12)$, fine sausage $(\mathrm{n}=7)$, ludová salami $(\mathrm{n}=11)$, durable heat-treated (DHT): inovecká salami $(n=15)$, cingovská salami $(n=18)$, touristic salami $(n=17)$. After sampling products were placed in clean sterile plastic bags, kept on ice and transported immediately to the laboratory for testing.

\section{DNA extraction}

DNA extraction was performed with PrepSEQ Rapid Spin Sample Preparation Kit (Applied Biosystems, USA) as a pre-preparation step for the Step One real-time PCR. A sample of $750 \mu \mathrm{L}$ was centrifuged

*Corresponding author: Miroslava Kačániová, Department of Microbiology, Faculty of Biotechnology and Food Sciences, Slovak University of Agriculture Tr. Andreja Hlinku 2, Nitra 949 76, Slovak Republic, Tel: 421-376-414-49; E-mail: miroslava.kacaniova@gmail.com

Received April 30, 2015; Accepted June 16, 2015; Published June 22, 2015

Citation: Kačániová M, Kluz M, Petrová J, Mellen M, Kunová S, et al. (2015) Incidence of Listeria monocytogenes in Meat Product Samples by Real-Time PCR. Mod Chem appl 3: 155. doi:10.4172/2329-6798.1000155

Copyright: @ 2015 Kačániová M et al., This is an open-access article distributed under the terms of the Creative Commons Attribution License, which permits unrestricted use, distribution, and reproduction in any medium, provided the original author and source are credited. 
for 3 minutes at maximum speed $(12,000)$. Supernatant was discarded and $50 \mu \mathrm{L}$ of Lysis Buffer was added to the pellet. Every sample was incubated for 10 minutes at $95^{\circ} \mathrm{C}$ [17].

\section{MicroSEQ Listeria monocytogenes detection kit}

Real-time Polymerase Chain Reaction (PCR) was used for detection of Listeria monocytogenes and TaqMan probe was applied for detection of the amplified sequence. Eight-tube strips which contained assay beads compatible with Step One ${ }^{\mathrm{TM}}$ Systems. Samples of $30 \mu \mathrm{L}$ were loaded to the lyophilized beads. MicroAmp 48 -Well Base and the MicroAmp ${ }^{\circ}$ Cap Installing Tool to the tubes were used. MicroAmp Fast 48-Well Tray on the sample block of the Step One System was performed. Real-time PCR procedure for the detection of strain is described in Figure 1.

\section{Real-time PCR}

We used PCR pathogen diagnostic AmpliSens kits, kits for the isolation of bacterial DNA - PrepSEQ Rapid Spin Sample Preparation Kit, MicroSEQ Listeria monocytogenes Detection Kit and SensiFast SYBR Hi-ROX kit for testing.

TaqMan probes labeled with both a fluorophore and aquencher dye were used in real-time PCR assays to detect amplification of specific DNA targets. We used three fluorophore detection chemistries that include $\mathrm{FAM}^{\mathrm{TM}}$ and $\mathrm{VIC}^{\circ}$ dye-labeled TaqMan MGB probebased assays, VIC and TAMRA ${ }^{\mathrm{TM}}$ dye-labeled probe-based assays and $\mathrm{ROX}^{\mathrm{TM}}$ as passive reference dye. FAM ${ }^{\mathrm{TM}}$, which has an emission of 520 $\mathrm{nm}$, has become the most commonly used fluorophore for single plex qPCR reactions. TAMRA ${ }^{\mathrm{TM}}$ will efficiently quench the fluorescence of $\mathrm{FAM}^{\mathrm{TM}}$ until the probe hybridizes to the target and is cleaved by the $5^{\prime}$ 'exonuclease activity of the polymerase. Thermal cycling conditions were: 2 minutes of incubation at $95^{\circ} \mathrm{C}$, followed by 40 cycles of $1 \mathrm{sec}$. denaturation at $95^{\circ} \mathrm{C}$ and 20 seconds annealing and elongation at $60^{\circ} \mathrm{C}$. Required data were collected during each elongation step. PCR products were detected by monitoring the increase of fluorescence on the reporter dye at each PCR cycle. Applied Biosystems software plotted the normalized reporter signal, $\Delta \mathrm{Rn}$, (reporter signal minus background) against the number of amplification cycles and also determined the threshold cycle $(\mathrm{Ct})$ value; i.e. the PCR cycle number at which fluorescence increases above a defined threshold level was used [17]. Samples with an increasing fluorescence signal were considered positive, regardless of the internal control amplification. Samples with no increasing fluorescence signal but with amplified internal control were considered negative. Samples with no fluorescence signal for both specific target and internal control were considered inhibited.

Sample (swabs from the inside of samples)

$$
\downarrow
$$

Isolation of DNA

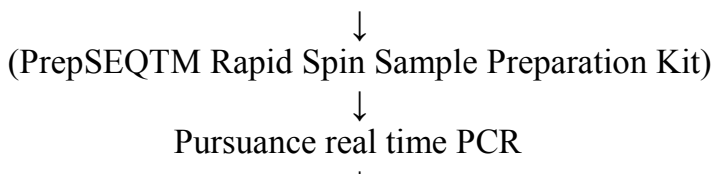

(MicroSEQ Listeria monocytogenes Detection Kit)

Figure 1: Real-time PCR procedure for the detection of the prevalence of Listeria monocytogenes.

\section{Results and Discussion}

Altogether 40 samples out of 100 tested were positive for Listeria monocytogenes with Step One real time PCR in our study. Regarding a type of the product, 17 out of 50 samples of Durable Heat-Treated (DHT) and 23 out of 50 samples of soft meat products (SMP) were positive for Listeria monocytogenes.

The results were evaluated based Ct values. The lowest value of 6.10 $\mathrm{Ct}$ was measured in a sample of the tourist sausage and the highest Ct value of 35.46 was recorded in the sample ipel'ska sausage and the average Ct value was 21.90 as it is shown in Table 1.

This shows us the positive samples of monitored pathogen and in which the cycle curves to ascend. In our case, the standard for pathogens was zero, so we quantified the amount of pathogens in a sample. Internal positive control (IPC) was positive for all our study samples indicating the correct course of the reaction.

We found out $40 \%$ samples which were positive of Listeria monocytogenes. Listeria species hasbeen associated with a wide variety of food sources particularly poultry, red meat and meat products [18]. The present study has recorded a high occurrence of Listeria spp. in pies (33\%) and chicken stew (28\%) (Figure 2). These findings are in line with those of other authors [18-20]. In Egypt, prevalence of Listeria (41\%) in meat and chicken products was [18] lower than reported in Malaysia (73.9\%) in imported frozen beef [21] and Turkey (83.3\%) in raw minced meat [20]. We know that foods are complex matrices. There are several publications that report about on filtration based protocols for PCR detection of various pathogenic species [22]; however, they have never been used with quantitative purposes. Most available detection systems require selective enrichment that steps to overcome the problem of potential PCR inhibitors, especially for low pathogen concentrations [23-26]. Remarkably, our method does not require any culture steps, meaning that results can be obtained considerably quicker (Table 2).

Regarding contamination of samples expressed as a percentage of all samples were evaluated ratatouille sausage SMP - 3.00\%, fine sausage SMP - 2\%, ham sausage SMP - 3.00\%, ipelská sausage SMP - 7.00\%, ludová salami SMP - 6.00\%, touristic salami DHT - 4.00\%, inovecká salami DHT - 5.00\%, cingovská salami DHT $-8.00 \%$ as it is shown in Table 2.

The presence of L. monocytogenes in a set of 250 samples of RTE meats, which were taken from different stores in Macon and Lee Counties, AL was investigated using microbiological culture by USDA technique and IMS+RT-PCR. There were found no L. monocytogenes in the fifty samples that were taken randomly from the 250 samples by means of IMS+RT-PCR. The same result was obtained by the standard methods. Whereas out of the total 250 samples checked first by microbiological methods, L. monocytogenes was found in 5 samples (2\%), two deli chickens and one Turkey deli meat, one Turkey sausage and one beef frankfurter [27].

A different real-time PCR assay for the detection of L. monocytogenes in food has been described [28-35]. The commercial availability of real-time PCR reagents and kits makes it easier for food companies to adapt real-time PCR testing to their laboratories. They also facilitate the development of common testing protocols and standards so that proper collaborative studies can be performed [36].

\section{Conclusion}

In terms of practicability, DNA-based method has potential to 
Citation: Kačániová M, Kluz M, Petrová J, Mellen M, Kunová S, et al. (2015) Incidence of Listeria monocytogenes in Meat Product Samples by RealTime PCR. Mod Chem appl 3: 155. doi:10.4172/2329-6798.1000155
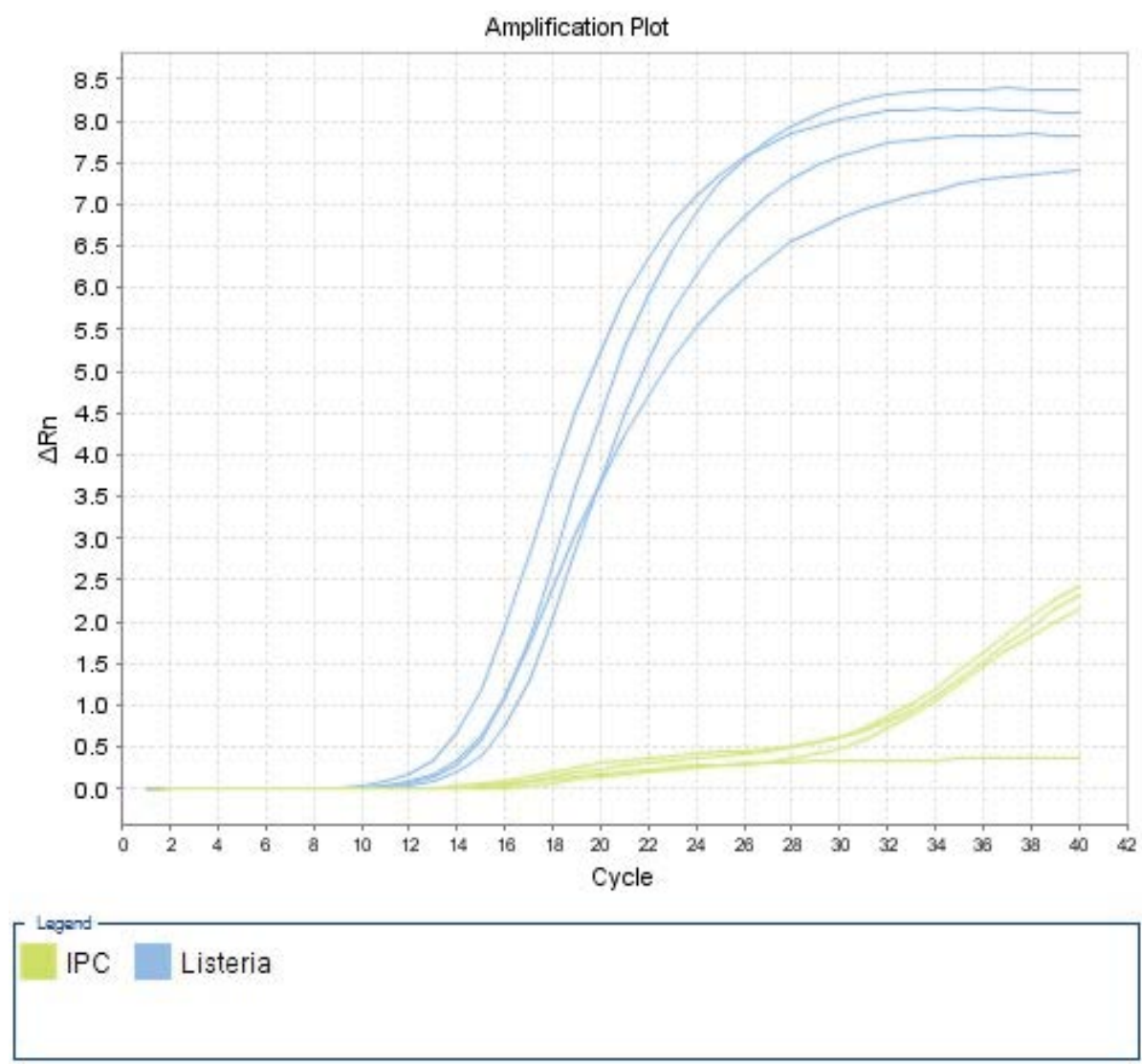

Figure 2: Real-time PCR detection of Listeria monocytogenes without incubation in meat product samples with internal positive control (IPC).

\begin{tabular}{|c|c|c|c|c|c|c|c|}
\hline \multirow[b]{2}{*}{$\begin{array}{l}\text { Number of } \\
\text { sample }\end{array}$} & \multirow[b]{2}{*}{ Meat product } & \multicolumn{2}{|c|}{ Ct-threshold cycle } & \multirow[b]{2}{*}{$\begin{array}{l}\text { Number of } \\
\text { samples }\end{array}$} & \multicolumn{3}{|c|}{ Ct-threshold cycle } \\
\hline & & $\begin{array}{c}\text { Listeria } \\
\text { monocytogenes }\end{array}$ & IPC & & Meat product & $\begin{array}{c}\text { Listeria } \\
\text { monocytogenes }\end{array}$ & IPC \\
\hline 1 & \multirow{5}{*}{$\begin{array}{c}\text { Ratatouille sausage } \\
\text { SMP }\end{array}$} & 16.23 & 29.69 & 21 & \multirow{3}{*}{ L'udová salami SMP } & 24.82 & 27.63 \\
\hline 2 & & 16.98 & 25.11 & 22 & & 29.06 & 27.53 \\
\hline 3 & & 16.59 & 17.31 & 23 & & 23.38 & 26.66 \\
\hline 4 & & 15.94 & 16.11 & 24 & \multirow{5}{*}{$\begin{array}{c}\text { Inovecká salami } \\
\text { DHT }\end{array}$} & 7.47 & 18.52 \\
\hline 5 & & 14.77 & 14.76 & 25 & & 27.46 & 29.46 \\
\hline 6 & \multirow{3}{*}{ Ham salami SMP } & 15.89 & 15.98 & 26 & & 14.34 & 17.88 \\
\hline 7 & & 19.44 & 28.60 & 27 & & 11.23 & 20.28 \\
\hline 8 & & 24.27 & 29.18 & 28 & & 32.96 & 29.07 \\
\hline 9 & \multirow{7}{*}{$\begin{array}{l}\text { Ipel'ská sausage } \\
\text { SMP }\end{array}$} & 23.06 & 29.39 & 29 & \multirow{8}{*}{$\begin{array}{c}\text { Čingovská salami } \\
\text { DHT }\end{array}$} & 9.78 & 29.74 \\
\hline 10 & & 19.49 & 26.39 & 30 & & 24.64 & 29.28 \\
\hline 11 & & 19.11 & 27.29 & 31 & & 25.00 & 28.03 \\
\hline 12 & & 28.95 & 30.94 & 32 & & 24.74 & 29.05 \\
\hline 13 & & 35.46 & 32.91 & 33 & & 24.85 & 27.80 \\
\hline 14 & & 31.90 & 32.14 & 34 & & 20.34 & 25.21 \\
\hline 15 & & 32.25 & 31.97 & 35 & & 24.70 & 28.11 \\
\hline 16 & \multirow{2}{*}{ Fine sausage SMP } & 34.39 & 32.58 & 36 & & 23.91 & 28.19 \\
\hline 17 & & 32.94 & 31.90 & 37 & \multirow{4}{*}{$\begin{array}{c}\text { Touristic salami } \\
\text { DHT }\end{array}$} & 21.64 & 25.09 \\
\hline 18 & \multirow{3}{*}{ L'udová salami SMP } & 30.97 & 31.45 & 38 & & 33.84 & 21.08 \\
\hline 19 & & 13.89 & 20.13 & 39 & & 11.74 & 30.63 \\
\hline 20 & & 11.58 & 16.13 & 40 & & 6.10 & 29.19 \\
\hline
\end{tabular}

Table 1: Real-time PCR detection of internal positive control of Listeria monocytogenes in meat product samples. 
Citation: Kačániová M, Kluz M, Petrová J, Mellen M, Kunová S, et al. (2015) Incidence of Listeria monocytogenes in Meat Product Samples by RealTime PCR. Mod Chem appl 3: 155. doi:10.4172/2329-6798.1000155

Page 4 of 5

\begin{tabular}{|c|c|c|c|c|c|c|}
\hline \multirow[b]{2}{*}{ Meat product } & \multicolumn{3}{|c|}{ Number of samples } & \multicolumn{3}{|c|}{ Number of samples (\%) } \\
\hline & Negative & Positive & Total & Negative & Positive & Total \\
\hline Ratatouille sausage SMP & 7 & 5 & 12 & 7.00 & 5.00 & 12.00 \\
\hline Fine sausage SMP & 5 & 2 & 7 & 5.00 & 2.00 & 7.00 \\
\hline Ham sausage SMP & 5 & 3 & 8 & 5.00 & 3.00 & 8.00 \\
\hline Ipel'ská sausage SMP & 5 & 7 & 12 & 5.00 & 7.00 & 12.00 \\
\hline L'udová salami SMP & 5 & 6 & 11 & 5.00 & 6.00 & 11.00 \\
\hline Meat products SMP & 27 & 23 & 50 & 27.00 & 23.00 & 50.00 \\
\hline Touristic salami DHT & 13 & 4 & 17 & 13.00 & 4.00 & 17.00 \\
\hline Inovecká salami DHT & 10 & 5 & 15 & 10.00 & 5.00 & 15.00 \\
\hline Čingovská salami DHT & 10 & 8 & 18 & 10.00 & 8.00 & 18.00 \\
\hline Meat product DHT & 33 & 17 & 50 & 33.00 & 17.00 & 50.00 \\
\hline Total meat product & 60 & 40 & 100 & 60.00 & 40.00 & 100.00 \\
\hline
\end{tabular}

Table 2: Incidence of Listeria monocytogenes in meat product samples.

be used for the positive screening of L. monocytogenes, and the major advantage the DNA based method is that it can detect $L$. monocytogenes without enrichments in meat products. However, it does need not more steps to perform and only approximately predicts the level of contamination in meat product. Our results indicate that the Step One real-time PCR assay indicated in this study could sensitively detect Listeria monocytogenes in meat product samples. The rapid real-time PCR-based method performed very well in comparison with the conventional method. It is a fast, simple, specific and sensitive way to detect nucleic acids which could be used in clinical diagnostic tests in the future.

\section{Acknowledgement}

The study was supported by the project: The research leading to these results has received funding from the European Community under project no 26220220180: Building Research Centre, Agro Biotech.

\section{References}

1. Centers for Disease Control and Prevention (CDC) (2000) Multistate outbreak of listeriosis--United States, 2000. MMWR Morb Mortal Wkly Rep 49: 1129 1130.

2. CDC (2002) Public health dispatch: Outbreak of Listeriosis-Northeastern United States, 2002. MMWR 51: 950-951.

3. Vázquez-Boland JA, Kuhn M, Berche P, Chakraborty T, Domínguez-Bernal G, et al. (2001) Listeria pathogenesis and molecular virulence determinants. Clin Microbiol Rev 14: 584-640.

4. Klein D (2002) Quantification using real-time PCR technology: applications and limitations. Trends Mol Med 8: 257-260.

5. Rocourt J, Hogue A, Toyofuku H, Jacquet C, Schlundt J (2001) Listeria and listeriosis: risk assessment as a new tool to unravel a multifaceted problem. Am J Infect Control 29: 225-227.

6. Wing EJ, Gregory SH (2002) Listeria monocytogenes: clinical and experimental update. J Infect Dis 185 Suppl 1: S18-24.

7. Peccio A, Autio T, Korkeala H, Rosmini R, Trevisani M (2003) Listeria monocytogenes occurrence and characterization in meat-producing plants. Lett Appl Microbiol 37: 234-238.

8. Rodríguez-Lázaro D, Hernández M, Pla M (2004) Simultaneous quantitative detection of Listeria spp. and Listeria monocytogenes using a duplex real-time PCR-based assay. FEMS Microbiol Lett 233: 257-267.

9. Navas J, Ortiz S, Lopez P, Jantzen MM, Lopez V, et al. (2006) Evaluation of effects of primary and secondary enrichment for the detection of Listeria monocytogenes by real-time PCR in retail ground chicken meat. Foodborne Pathog Dis 3: 347-354
10. Rossmanith $P$, Krassnig M, Wagner M, Hein I (2006) Detection of Listeria monocytogenes in food using a combined enrichment/real-time PCR method targeting the prfA gene. Res Microbiol 157: 763-771.

11. Oravcová K, Trncíková T, Kaclíková E (2007) Comparison of three real-time PCR-based methods for the detection of Listeria monocytogenesin food. $J$ Food Nutr Res 46: 63-67.

12. Rodríguez-Lázaro $D$, Hernández $M$, Scortti M, Esteve T, Vázquez-Boland JA et al. (2004) Quantitative detection of Listeria monocytogenes and Listeria innocua by real-time PCR: assessment of hly, iap, and lin02483 targets and AmpliFluor technology. Appl Environ Microbiol 70: 1366-1377.

13. Norton DM (2002) Polymerase chain reaction-based methods for detection of Listeria monocytogenes: toward real-time screening for food and environmental samples. J AOAC Int 85: 505-515.

14. O’ Grady J, Sedano-Balbás S, Maher M, Smith T, Barry T (2008) Rapid realtime PCR detection of Listeria monocytogenes in enriched food samples based on the ssrA gene, a novel diagnostic target. Food Microbiol 25: 75-84.

15. O'Grady J, Ruttledge M, Sedano-Balbás S, Smith TJ, Barry T, et al. (2009) Rapid detection of Listeria monocytogenes in food using culture enrichment combined with real-time PCR. Food Microbiol 26: 4-7.

16. Rodríguez-Lázaro D, Hernandez M (2006) Molecular methodology in Food Microbiology diagnostics: trends and current challenges. IUFoST World Congress, pp. 1085-1099.

17. Pochop J, Kačániová M, Hleba L, Lopasovský L, Bobková A, et al. (2012) Detection of Listeria monocytogenes in ready-to-eat food by Step One real-time polymerase chain reaction. J Environ Sci Health B 47: 212-216.

18. El-Malek AMA, Ali SFH, Hassanein R, Moemen AM, Elsayh KI, et al. (2010) Occurrence of Listeria species in meat, chicken products and human stools in Assiut city, Egypt with PCR use for rapid identification of Listeria monocytogenes. Vet World 3: 353-359.

19. Molla B, Yilma R, Alemayehu D (2004) Listeria monocytogenes and othe Listeria species in retail meat and milk products in Addis Ababa, Ethiopia. Ethiop J Health Dev 18: 208-212.

20. Yucel N, Citak S, Onder M (2005) Prevalence and antibiotic resistance of Listeria species in meat products in Ankara, Turkey. Food Microbiol 22: 241 245.

21. Hassan Z, Purwati E, Radu S, Rahim RA, Rusul G (2001) Prevalence of Listeria spp and Listeria monocytogenes in meat and fermented fish in Malaysia. Southeast Asian J Trop Med Public Health 32: 402-407.

22. Rijpens NP, Herman LM (2002) Molecular methods for identification and detection of bacterial food pathogens. J AOAC Int 85: 984-995.

23. Al-Soud WA (2000) Optimisation of diagnostic PCR a study of PCR inhibitors in blood and sample pretreatment. Ph.D. thesis. Lund University, Lund, Sweden. 
Citation: Kačániová M, Kluz M, Petrová J, Mellen M, Kunová S, et al. (2015) Incidence of Listeria monocytogenes in Meat Product Samples by RealTime PCR. Mod Chem appl 3: 155. doi:10.4172/2329-6798.1000155

Page 5 of 5

24. Abu Al-Soud W, Rådström P (2000) Effects of amplification facilitators on diagnostic PCR in the presence of blood, feces, and meat. J Clin Microbiol 38 . 4463-4470.

25. Al-Soud WA, Rådström $P$ (2001) Purification and characterization of PCRinhibitory components in blood cells. J Clin Microbiol 39: 485-493.

26. Bhagwat AA (2003) Simultaneous detection of Escherichia coli O157:H7, Listeria monocytogenes and Salmonella strains by real-time PCR. Int J Food Microbiol 84: 217-224.

27. Abdelgadir AMMA, Srivastava KK, Gopal Reddy P (2009) Detection of Listeria monocytogenes in Ready-to-Eat Meat Products. Am J Anim Vet Sci 4: 101-107.

28. Nogva HK, Rudi K, Naterstad K, Holck A, Lillehaug D (2000) Application of 5'-nuclease PCR for quantitative detection of Listeria monocytogenes in pure cultures, water, skim milk, and unpasteurized whole milk. Appl Environ Microbiol 66: 4266-4271.

29. Hough AJ, Harbison SA, Savill MG, Melton LD, Fletcher G (2002) Rapid enumeration of Listeria monocytogenes in artificially contaminated cabbage using real-time polymerase chain reaction. J Food Prot 65: 1329-1332.

30. Koo K, Jaykus LA (2003) Detection of Listeria monocytogenes from a model food by fluorescence resonance energy transfer-based PCR with an asymmetric fluorogenic probe set. Appl Environ Microbiol 69: 1082-1088.
31. Rodríguez-Lázaro $D$, Jofré A, Aymerich T, Hugas M, Pla M (2004) Rapid quantitative detection of Listeria monocytogenes in meat products by real-time PCR. Appl Environ Microbiol 70: 6299-6301.

32. Rodríguez-Lázaro D, Jofré A, Aymerich T, Garriga M, Pla M (2005) Rapid quantitative detection of, Listeria monocytogenes in salmon products: evaluation of pre-real-time PCR strategies. J Food Prot 68: 1467-1471.

33. Rodríguez-Lázaro D, Pla M, Scortti M, Monzó HJ, Vázquez-Boland JA (2005) A novel real-time PCR for Listeria monocytogenes that monitors analytical performance via an internal amplification control. Appl Environ Microbiol 71 9008-9012.

34. Berrada H, Soriano JM, Picó Y, Mañes J (2006) Quantification of Listeria monocytogenes in salads by real time quantitative PCR. Int J Food Microbiol 107: 202-206.

35. Oravcová K, Kaclíková $E$, Krascsenicsová K, Pangallo $D$, Brezná $B$, et al. (2006) Detection and quantification of Listeria monocytogenes by 5'-nuclease polymerase chain reaction targeting the actA gene. Lett Appl Microbiol 42: 1518.

36. Janzten MM, Navas J, Corujo A, Moreno R, López V, et al. (2006) Review. Specific detection of Listeria monocytogenes in foods using commercial methods: from chromogenic media to real-time PCR. Spanish J Agric Res 3: 235-247. 